\title{
Surface Modification of Titanium by Plasma Nitriding
}

\author{
Myriam Pereira Kapczinski ${ }^{\mathrm{a}}$, Carlos Gil ${ }^{\mathrm{b}}$, Eder Julio Kinast ${ }^{\mathrm{c}}$, Carlos Alberto dos Santos ${ }^{\mathrm{c} *}$ \\ ${ }^{\mathrm{a}}$ Faculdade de Odontologia - ULBRA \\ Rua Miguel Tostes, 101, 92420-280 Canoas - RS, Brazil \\ ${ }^{\mathrm{b}}$ Faculdade de Odontologia - USP \\ Av. Prof. Lineu Prestes 2227, 05508-900 São Paulo - SP, Brazil \\ ${ }^{\mathrm{c}}$ Instituto de Física - UFRGS \\ C.P. 15051, Campus do Vale, 91501-970 Porto Alegre - RS, Brazil
}

Received: November 5, 2002; Revised: February 23, 2003

\begin{abstract}
A systematic investigation was undertaken on commercially pure titanium submitted to plasma nitriding. Thirteen different sets of operational parameters (nitriding time, sample temperature and plasma atmosphere) were used. Surface analyses were performed using X-ray diffraction, nuclear reaction and scanning electron microscopy. Wear tests were done with stainless steel Gracey scaler, sonic apparatus and pin-on-disc machine. The obtained results indicate that the tribological performance can be improved for samples treated with the following conditions: nitriding time of $3 \mathrm{~h}$; plasma atmosphere consisting of $80 \% \mathrm{~N}_{2}+20 \% \mathrm{H}_{2}$ or $20 \% \mathrm{~N}_{2}+80 \% \mathrm{H}_{2}$; sample temperature during nitriding of 600 or $800{ }^{\circ} \mathrm{C}$.
\end{abstract}

Keywords: plasma nitriding, tribology, titanium, dental implants

\section{Introduction}

The biocompatibility and good corrosion resistance of commercially pure titanium (c.p. Ti) has motivated its use in medical procedures. The osseointegrated titanium implants are reliable alternatives for safety and long time treatment, representing advancement in the clinical practice mostly in dental prosthetic ${ }^{1-4}$. However, occasionally the use of c.p. Ti as implant is problematic as long as it presents low wear resistance ${ }^{5,6}$.

A crucial issue concerning the removal of the bacterial plaque from the transmucous dental implant cylinders is the possibility of damage by the routine instruments, such as stainless steel Gracey scaler, sonic and ultrasonic apparatus $^{7-10}$. Such an obstacle has been bypassed using mild instrumental, but the results are not satisfactory. An obvious alternative would be the surface modification of the transmucous cylinders to provide better wear resistance. In fact, this has been the subject of several investigations in clinical dentistry ${ }^{4}$. Among the surface treatment techniques, the most reported are: plasma assisted chemical vapor deposition $^{5}$, conventional ion implantation ${ }^{15-19}$, plasma source nitrogen ion implantation ${ }^{20}$, conventional nitriding ${ }^{21}$, con- ventional plasma nitriding ${ }^{22,23}$, intensified plasma ion nitriding ${ }^{24}$, physical and chemical vapor deposition TiN films ${ }^{25-28}$, powder immersion reaction assisted coating method $^{29}$, laser heating ${ }^{30,31}$ as well as combined techniques ${ }^{32,33}$. Improvement on the mechanical and tribological properties of c.p. Ti and its alloys have been reported ${ }^{11-14}$.

Aiming the use in clinical procedures, we have started a systematic study on surface treatment of c.p. Ti. Thin film deposition, ion implantation and plasma nitriding are available at our laboratories. We intend to investigate all these processes, but due to recent technological interest we firstly decided to approach the plasma nitriding technique, whose results will be discussed in this paper.

\section{Experimental}

\subsection{Sample preparation}

Samples from the same ingot of commercially pure $\mathrm{Ti}$ (Atomergic Chemetals) were ground flat and mechanically polished to a $0.5 \mu \mathrm{m}$ diamond finish and nitrided in conventional d.c. plasma-nitriding equipment similar to those previously described ${ }^{34,35}$. Preceding nitriding the specimens

*e-mail: cas@if.ufrgs.br 
were ultrasonically cleaned in acetone and dried in air. Nitriding processing followed the same procedures: (i) cleaning of the treatment chamber through a four-step filling-evacuation process with nitrogen; (ii) voltage in the range from 370 to $700 \mathrm{~V}$ and current density from 2.5 to $5.0 \mathrm{~mA} / \mathrm{cm}^{2}$ were adjusted to maintain the cathode temperature between 400 and $800{ }^{\circ} \mathrm{C}$; (iii) after treatment the samples were cooled in the treatment chamber with a nitrogen atmosphere.

As previously reported for Ti-6Al-4V alloy, the total pressure has a quite little effect on the surface composition of the nitrided samples ${ }^{36}$. Therefore, this parameter was allowed to vary between 0.5 and $7.5 \times 10^{-2} \mathrm{~Pa}$. Three different plasma compositions (nitriding atmosphere) were used $\left(80 \% \mathrm{~N}_{2}-20 \% \mathrm{H}_{2}, 60 \% \mathrm{~N}_{2}-40 \% \mathrm{H}_{2}, 20 \% \mathrm{~N}_{2}-80 \% \mathrm{H}_{2}\right)$. The time treatment varied between 3 and $9 \mathrm{~h}$. For each operational condition, two samples were prepared in the same batch.

\subsection{Sample characterization}

$\mathrm{X}$-ray diffraction (XRD) measurements, in $\theta-2 \theta$ geometry (Bragg-Brentano goniometer) were carried out in a Siemens diffractometer with monochromated $\mathrm{Co} \mathrm{K} \alpha$ radiation $\left(\lambda_{1}=1.78896 \AA\right.$ and $\left.\lambda_{2}=1.79285 \AA\right)$. All the patterns were obtained in the $2 \theta$ range between $20^{\circ}$ and $110^{\circ}$, with scan step of $0.05^{\circ} 2 \theta$ with a counting time of $2 \mathrm{~s}$. The profile parameters were obtained using Rietveld refinement with the program FullProf ${ }^{37,38}$. Starting lattice parameters were taken from JCPDS ${ }^{39}$ files 44-1294 (for $\alpha$-Ti), 41-1352 (for $\mathrm{TiN}_{\mathrm{x}}$ ) and 38-1420 (for TiN).

Scanning electron microscopy (SEM) micrographs were obtained using Phillips XL 20 microscope equipped with energy-dispersive X-ray spectrometer (EDX). Nitrogen depth profiles were obtained from ${ }^{14} \mathrm{~N}(\mathrm{p}, \gamma){ }^{15} \mathrm{O}$ nuclear reaction (RNA) using the $400 \mathrm{kV}$ ion implanter at the Institute of Physics - UFRGS, with protons accelerated to $278 \mathrm{keV}$. The $\mathrm{N}$ concentration (in at.\%) is given by

$$
N=\frac{57}{C_{c a l}} C_{\text {sam }} \frac{S_{c a l}}{S_{\text {sam }}}
$$

where, $\mathrm{C}_{\text {cal }}$ and $\mathrm{S}_{\text {cal }}$ are the count and the stopping power for the calibration $\left(\mathrm{Si}_{3} \mathrm{~N}_{4}\right)$, while $\mathrm{C}_{\text {sam }}$ and $\mathrm{S}_{\text {sam }}$ stand for the same parameters for the sample ${ }^{40}$. Surface roughness measurements were made using a Talysurf 5M (Ranck Taylor Hobson) profilometer on all the samples, except for those submitted to pin-on-disc tests. Typical errors are $\pm 10 \%$.

\subsection{Tribological experiments}

To simulate clinical procedures, wear tests were performed with stainless steel Gracey scaler (SS White Duflex G11-G12) and sonic apparatus (Sonicborden 2000 N, Kavo) with universal tip \#5. Both are commercial equipments used in the clinical routine. Each sample $(20 \times 10 \times 1 \mathrm{~mm})$ was demarcated in three regions. The central one was kept intact for control while the others were submitted to the tests. Two hundred unidirectional strokes were done with the Gracey scaler. The tests with the sonic apparatus were performed with bidirectional motion during $60 \mathrm{~s}$, under uninterrupted water and air sprays. All the tests were performed manually by a single person, which was well trained to be reproductive.

The generic denomination "pin-on-disc" (POD) test is used for tests where a disc rotate under a pin that can have various formats (ASTM standard ${ }^{41}$ ). Although the use of ball instead of pin is increasing, the POD denomination continue to be used. The POD tests were performed in a tribometer (TE79 Plint \&Partners) using AISI 52100 balls of $6 \mathrm{~mm}$ in diameter. The experiments were done during $600 \mathrm{~s}$ in air without lubrication, at $\cong 27^{\circ} \mathrm{C}$ and relative humidity between $50 \%$ and $60 \%$. A normal load of $4 \mathrm{~N}$ was applied on a rotating disk with $120 \mathrm{RPM}$ and $3 \mathrm{~mm}$ of radius.

\section{Results}

Firstly, all the samples were submitted to tests with the sonic apparatus. Excepting for samples treated with $600{ }^{\circ} \mathrm{C}$, $80 \% \mathrm{~N}_{2}-20 \% \mathrm{H}_{2}, 3 \mathrm{~h}, 2 \times 10^{-2} \mathrm{~Pa}$ and $800{ }^{\circ} \mathrm{C}, 20 \% \mathrm{~N}_{2}-80 \% \mathrm{H}_{2}$, $3 \mathrm{~h}, 2 \times 10^{-2} \mathrm{~Pa}$, all the others, including the c.p. Ti one, have shown severe damages after the test. Besides good wear performance, the sample treated at $600{ }^{\circ} \mathrm{C}$ shows coloration similar to that of the as-received one. Therefore, concerning clinical application this is the best condition. Several samples were prepared with the same operational parameters, but in different batches to evaluate the process reproducibility. The obtained result is quite favorable. In the following, the treated sample means that one nitrided at $600{ }^{\circ} \mathrm{C}$.

SEM photomicrographs for c.p. Ti and nitrided sample are shown in Figs. 1a and 1b respectively. Surface roughness measurements indicated that the treatment increases the roughness parameter $\mathrm{R}_{\mathrm{a}}$ (mean arithmetic deviation from the median line of the surface profile) from $0.076 \mu \mathrm{m}$ (aspolished surface) to about $0.134 \mu \mathrm{m}$. Similar increasing on $\mathrm{R}_{\mathrm{a}}$ has been early reported for c.p. Ti submitted to intensified plasma ion nitriding ${ }^{42}$. Figures $2 \mathrm{a}$ and $2 \mathrm{~b}$ show SEM photomicrographs, respectively for c.p. Ti and nitrided sample submitted to test with the sonic apparatus. The areas in both figures are within the scratch of the tool. As can be seen the test with the sonic apparatus produced roughening of the surface and material loss on c.p. Ti $\left(\mathrm{R}_{\mathrm{a}} 0.122 \mu \mathrm{m}\right)$. Contrary, no macroscopic signal of damage was observed on the nitrided sample, only a subtle increasing of the brightness, which can be due to surface depressions observed 


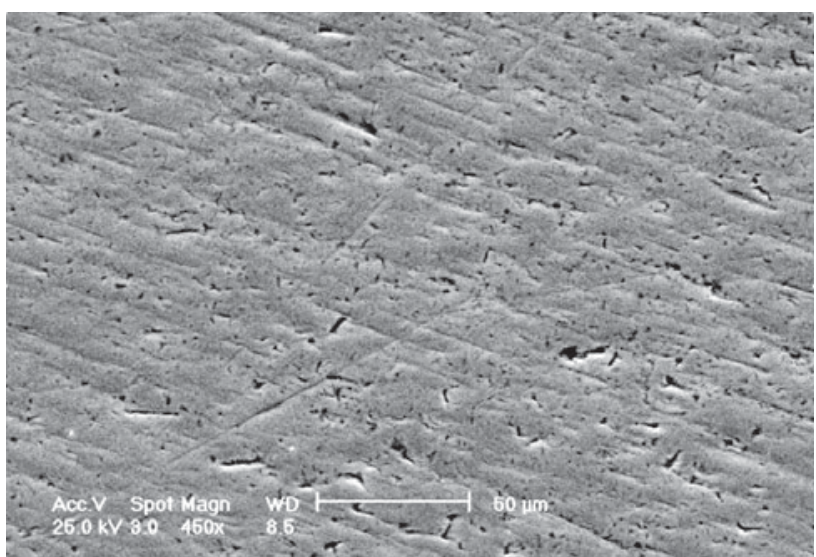

a)

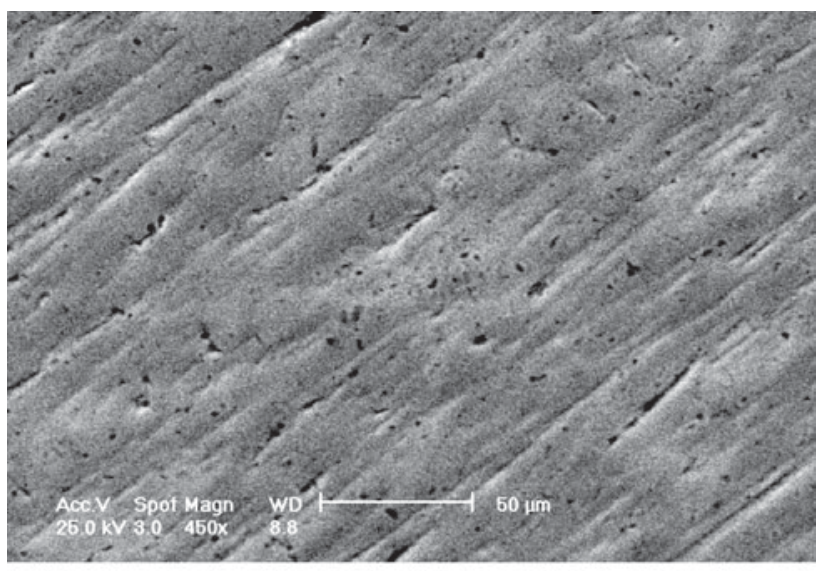

b)

Figure 1. SEM photomicrographs under $450 \times$ magnification of (a) c.p. Ti; (b) nitrided sample.

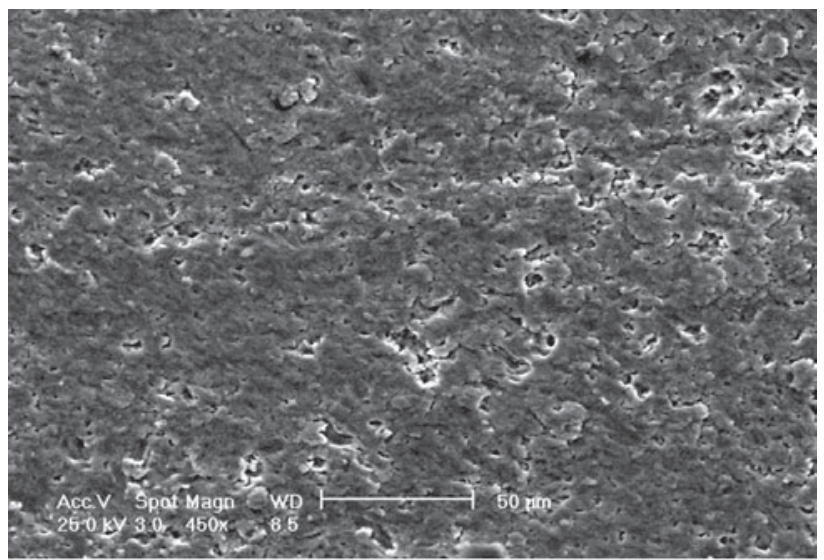

a)

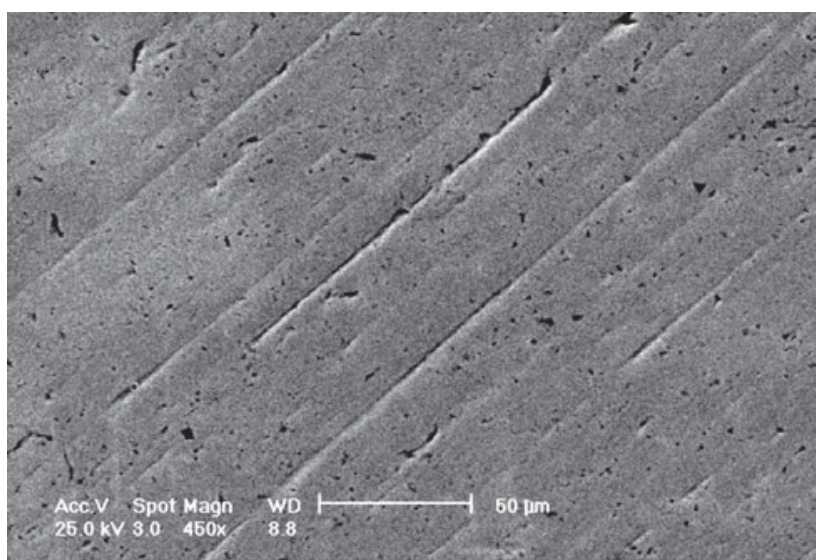

b)

Figure 2. SEM photomicrographs under 450× magnification after test with sonic apparatus in (a) c.p. Ti; (b) nitrided sample.

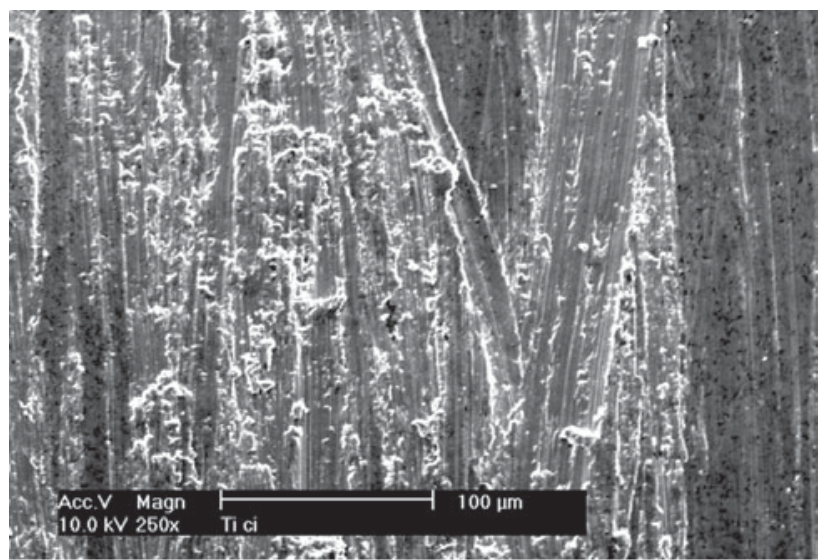

a)

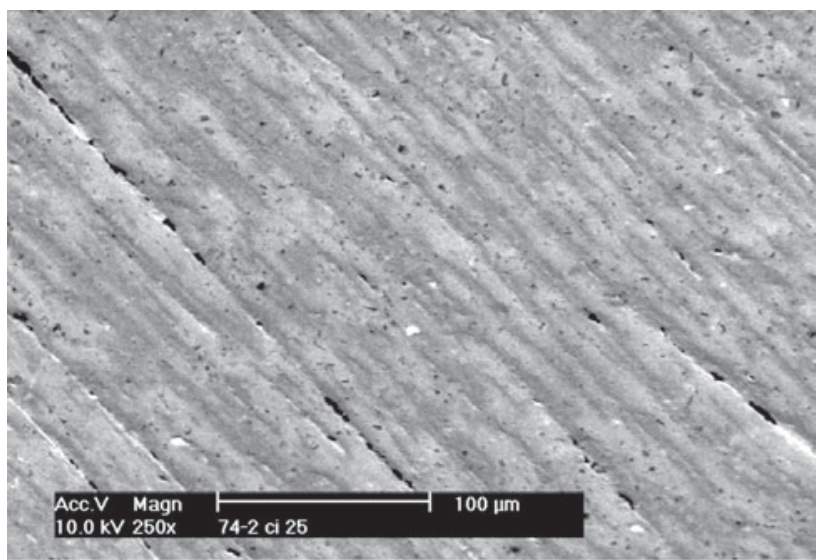

b)

Figure 3. SEM photomicrographs under 250× magnification after test with Gracey scaler in (a) c.p. Ti; (b) nitrided sample. 


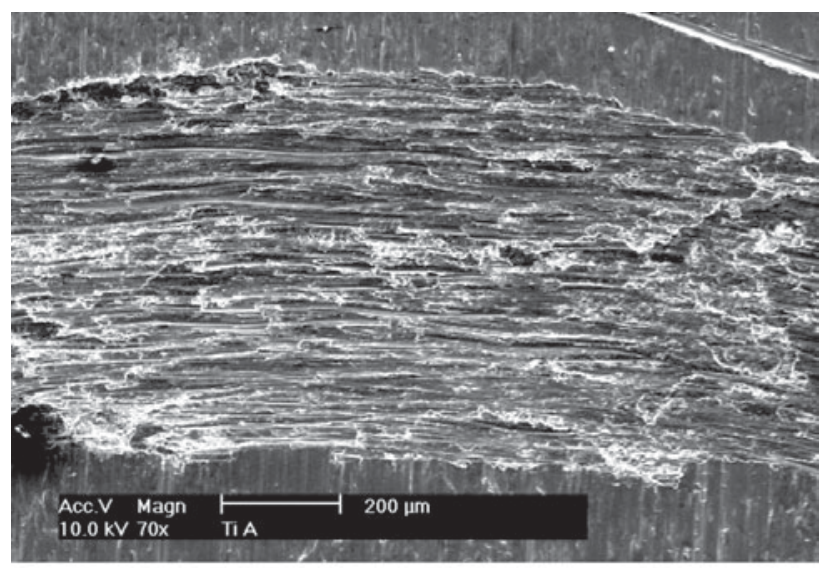

a)

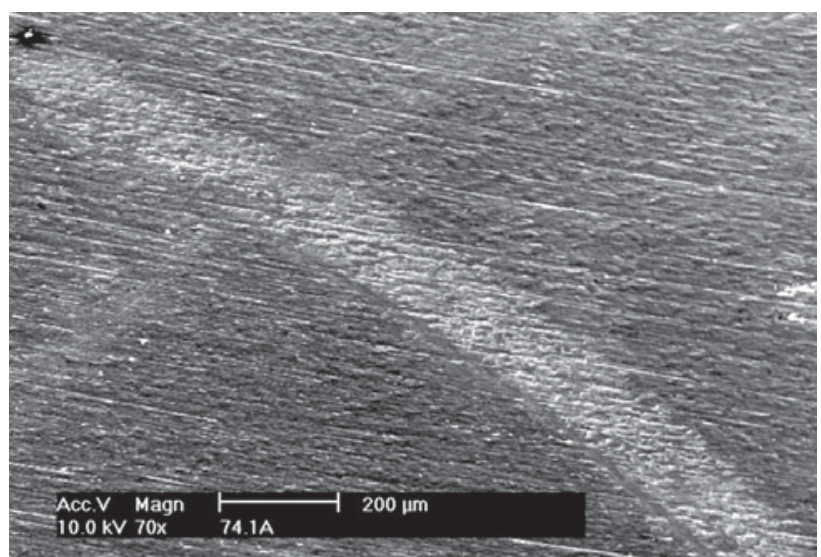

b)

Figure 4. SEM photomicrographs under 70× magnification after POD test in (a) c.p. Ti; (b) nitrided sample.

under $450 \times$ SEM magnification (Fig. 2b). The $\mathrm{R}_{\mathrm{a}}$ parameter was $0.141 \mu \mathrm{m}$ in this surface. Patches and abrasions on the photomicrography shown in Fig. 3a indicate that c.p. Ti sample was strongly damaged after test with the Gracey scaler $(\mathrm{R} \cong 0.143 \mu \mathrm{m})$, while the nitrided sample (Fig. 3b) appeared smoother after this test $(0.098 \mu \mathrm{m})$. That is to say, while the as-nitrided sample exhibited $\mathrm{R}_{\mathrm{a}} \cong 0.134 \mu \mathrm{m}$, the nitrided sample submitted to Gracey scaler test exhibited $\mathrm{R}_{\mathrm{a}} \cong 0.098$.

Figure 4a shows the photomicrography of c.p. Ti submitted to POD test. The wear track $(\cong 0.7 \mathrm{~mm})$ exhibits many grooves typical of abrasive wear. For the nitrided sample, the ball track exhibited a brightness which can be attributed to surface dent. No signal of scratch was observed on this sample (see Fig. 4b). Nevertheless, as illustrated in Fig. 5, a 250× magnification photomicrography exhibited adhered material (see the inset in Fig. 5). Energy-dispersive X-ray spectrometry (EDS) performed on these wear particles showed the presence of iron and oxygen, suggesting they are from the steel ball.

The coefficient of friction $(\mu)$ as a function of the sliding time for the control and nitrided samples are shown in Fig. 6. The features are typical. After an initial period of about $200 \mathrm{~s}$ (400 revolutions) for the control sample and about $300 \mathrm{~s}$ for the nitrided sample (batch \#1), the coefficient of friction increases from $\cong 0.35$ to $\cong 0.50$ and from $\cong 0.10$ to $\cong 0.50$, respectively. Such a behavior can be attributed to two effects, which play in a synergetic way. From one side, the consummation of the protective layer leaves the surface more weak against wear. On the other hand, the debris so produced increase the coefficient of friction. Thus, for c.p. Ti, the native oxide layer is supposedly protective against mild wear test, while for the nitrided sample the surface layer can tolerate more severe tests. In this sense, it is interesting to point out other differences among the re-

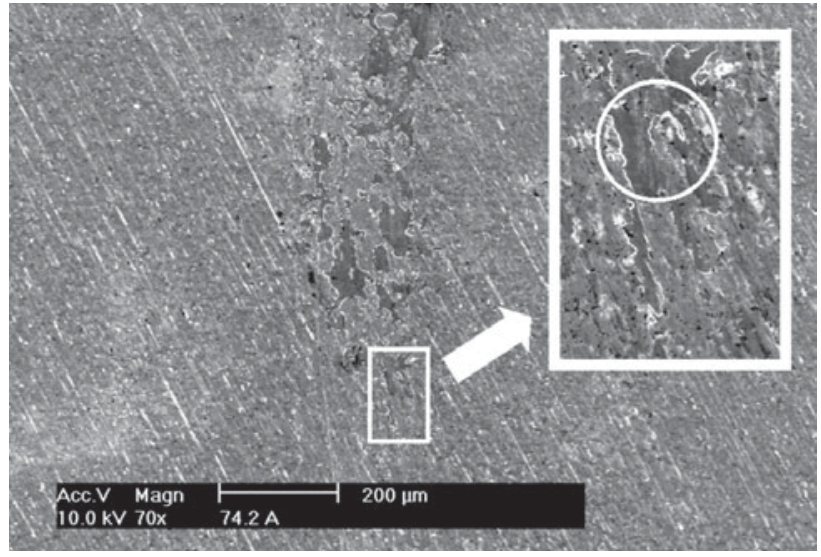

Figure 5. SEM photomicrographs under 70× magnification after POD test in a nitrided sample. The circle in the inset shows where EDS was performed.

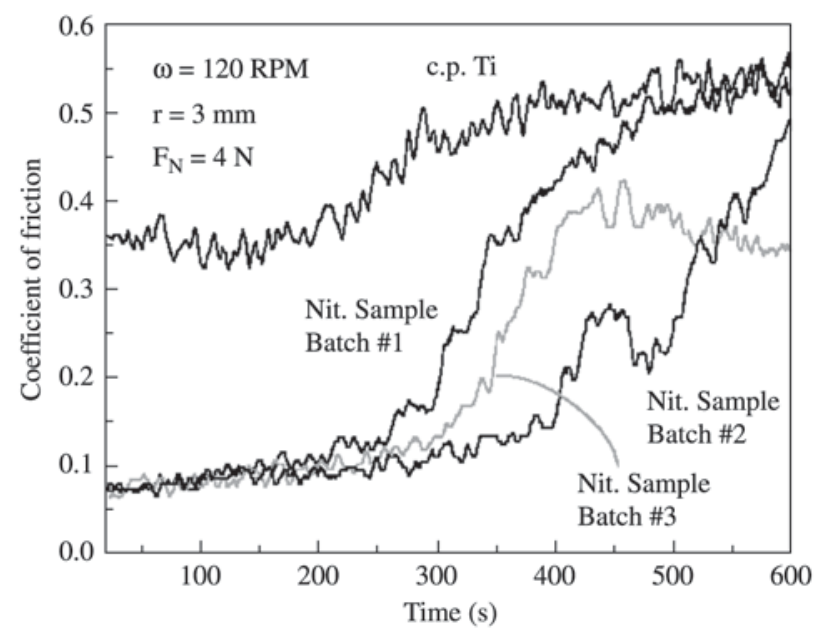

Figure 6. Coefficient of friction as a function of the sliding time for the control and nitrided samples. 
sults obtained for these samples. Firstly, the initial value of $\mu$ for the nitrided sample is about 3 times smaller than for c.p. Ti. Second, the features exhibited by the nitrided sample suggest that the wear is of the abrasive type, as this pattern is typical of wear particles at the sliding interface ${ }^{42,43}$. To properly discuss such a process it is interesting to have some insight on the physicochemical state of the sliding surfaces. As discussed below, we approached this point performing XRD and NRA measurements.

Figure 7 displays significant parts of the XRD patterns for the control and nitrided sample batch \#1 (all batches gave quite similar patterns). The patterns were fitted by means of a Rietveld procedure, whose results are summarized in Table 1. The main contribution in each one of the spectra is due to $\alpha-\mathrm{Ti}$, whereas the minor ones are due to different titanium nitrides and $\operatorname{Ti}(\mathrm{N})$ solid solutions. The nitrided sample exhibited cubic phase TiN in addition to hexagonal phases $\alpha$-Ti and $\alpha-\mathrm{TiN}_{\mathrm{x}}{ }^{44}$. The $\alpha$-Ti phase is present with three different cell-parameter values, which we named $\alpha$-Ti(1), $\alpha$-Ti(2) and $\alpha$-Ti(3). These phases can be attributed to different $\mathrm{N}$-saturated á-phases or to substoichiometric phases similar to $\alpha-\mathrm{TiN}_{0.25}{ }^{18}, \alpha-\mathrm{TiN}_{0.26}$ (JCPDS file 44-1095) or $\alpha-\mathrm{TiN}_{0.30}$ (JCPDS file 41-1352).

To better understand such a result we have performed NRA to access the near-surface nitrogen concentration. As shown in Fig. 8, between $50 \mathrm{~nm}$ and $250 \mathrm{~nm}$ the $\mathrm{N}$ concentration is higher than 25 at.\%. Between $250 \mathrm{~nm}$ and $400 \mathrm{~nm}$ the concentration is between 25 at. $\%$ and 15 at. $\%$. The nearsurface layer could provides precipitation of $\delta$-TiN, while the deeper one would be consistent with $\varepsilon-\mathrm{Ti}_{2} \mathrm{~N}$ precipitation $^{19,42,45}$. The lack of reflections attributed to $\varepsilon-\mathrm{Ti}_{2} \mathrm{~N}$ in

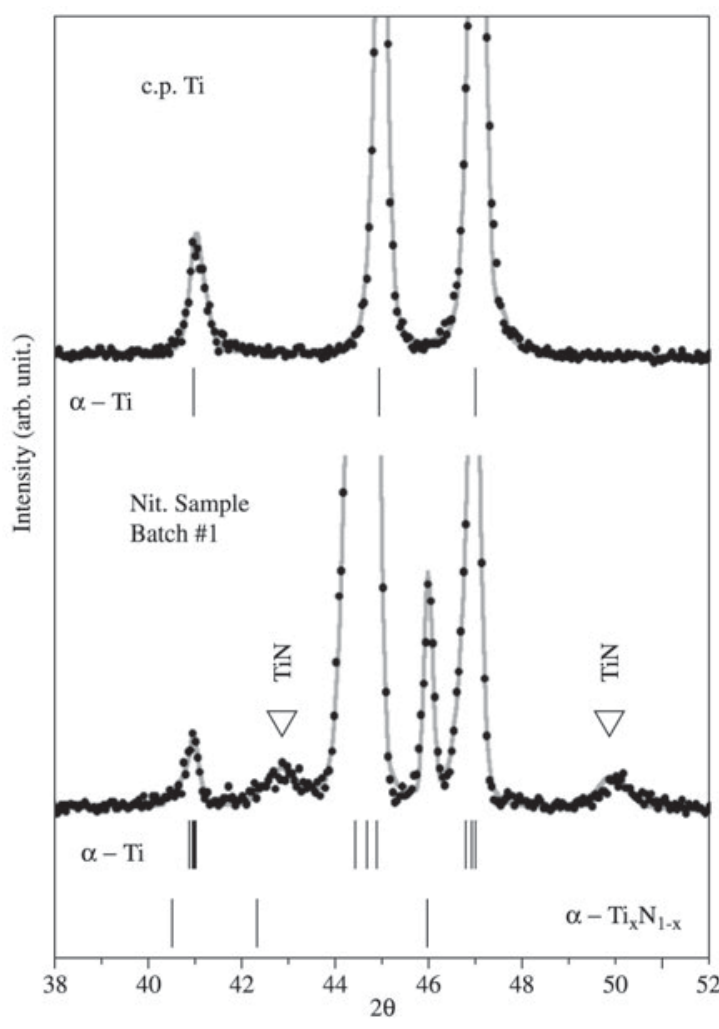

Figure 7. Rietveld analysis (solid line) of XRD patterns (experimental points) for c.p. Ti and nitrided sample. The a-Ti, a-TiN reflections are indicated by vertical bars. Those for TiN and indicated by triangles.

Table 1. Cell-unit parameters and agreement factor $R_{B}$ for sample nitrided at different batches. Numbers in brackets designate $\pm 1 \mathrm{~s}$ on the last decimal given.

$$
R_{B}=100 \sum_{k} \mid I_{k}(o b s)-I_{k}(\text { calc }) \mid / \sum_{k} I_{k}(o b s)
$$

\begin{tabular}{|c|c|c|c|c|c|c|}
\hline \multirow[b]{2}{*}{ Phase } & \multicolumn{2}{|c|}{ Batch 1} & \multicolumn{2}{|c|}{ Batch 2} & \multicolumn{2}{|c|}{ Batch 3} \\
\hline & $\begin{array}{l}\text { a }(\AA) \\
\text { c }(\AA)\end{array}$ & $\mathrm{R}_{\mathrm{B}}(\%)$ & $\begin{array}{l}\mathrm{a}(\AA) \\
\mathrm{c}(\AA)\end{array}$ & $\mathrm{R}_{\mathrm{B}}(\%)$ & $\begin{array}{l}\mathrm{a}(\AA) \\
\mathrm{c}(\AA)\end{array}$ & $\mathrm{R}_{\mathrm{B}}(\%)$ \\
\hline \multirow[t]{2}{*}{$\alpha-\operatorname{Ti}(1)$} & $2.959(8)$ & 1.16 & $2.958(5)$ & 1.31 & $2.960(3)$ & 1.34 \\
\hline & $4.731(7)$ & & $4.728(6)$ & & $4.726(5)$ & \\
\hline \multirow[t]{2}{*}{$\alpha-\operatorname{Ti}(2)$} & $2.950(7)$ & 2.46 & $2.952(0)$ & 1.74 & $2.951(8)$ & 1.98 \\
\hline & $4.687(8)$ & & $4.688(5)$ & & $4.687(9)$ & \\
\hline \multirow[t]{2}{*}{$\alpha-\operatorname{Ti}(3)$} & $2.953(3)$ & 1.04 & $2.954(5)$ & 1.06 & $2.954(6)$ & 0.928 \\
\hline & $4.709(1)$ & & $4.722(3)$ & & $4.708(0)$ & \\
\hline \multirow[t]{2}{*}{ TiN } & $4.24(4)$ & 4.06 & $4.24(7)$ & 5.25 & $4.24(2)$ & 3.67 \\
\hline & $4.24(4)$ & & $4.24(7)$ & & $4.24(2)$ & \\
\hline \multirow[t]{2}{*}{$\operatorname{TiN}_{x}$} & $2.984(0)$ & 3.30 & $2.982(7)$ & 1.61 & $2.983(9)$ & 2.62 \\
\hline & $4.95(7)$ & & 4.97(9) & & $4.96(0)$ & \\
\hline
\end{tabular}




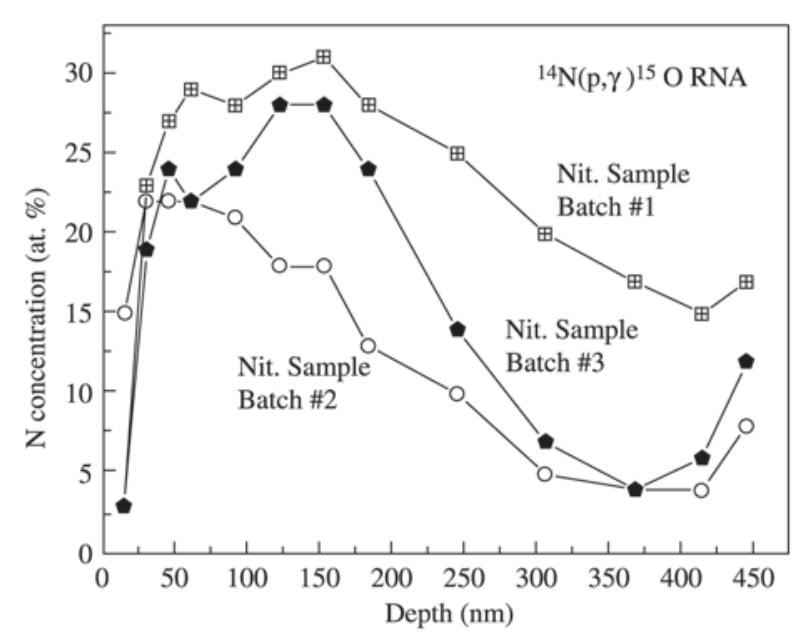

Figure 8. Near-surface nitrogen concentration as a function of the depth for nitrided sample. The solid line is a guide to the eyes.

Fig. 7 is probably because its layer thickness is below the detection limit for $\mathrm{Co} \mathrm{K} \alpha$ radiation.

\section{Discussion}

The test with the sonic apparatus produced on c.p. Ti an effect similar to those observed after tests with Implacare scaler and Cavitron ${ }^{7,10}$. As shown in Fig. 2a, roughening of the surface and material loss are evident. In this sense, a meaningful difference is observed when compared to the results obtained for the nitrided sample, which does not show any apparent surface damage, even at microscopic level (Fig. 2b). Taking into account data from Brookshire et al. ${ }^{46}$, the present tests are comparable to several years of implant maintenance. The different $\alpha$-Ti phases detected with XRD analysis can be attributed to nitrogen, as well as to oxygen present in interstitial sites. In fact, the presence of oxide in this material is well known and has been reported by Brånemark et al. ${ }^{2}$.

Now, let us discuss the correlation between near-surface composition and tribological behavior. During the first step of the sliding experiment (up to $\cong 300 \mathrm{~s}$ for the nitrided sample), surface oxidation is promoted by the increasing of the temperature in the contact zone. As $\alpha-\mathrm{TiN}_{\delta}$ reacts strongly with oxygen ${ }^{19}$, a oxynitride layer quickly growth with the sliding time, resulting in a low friction coefficient. When this layer reaches a critical thickness it will peel off, producing debris and increasing the friction coefficient.

\section{Summary and Conclusion}

Near-surface composition and tribological behavior of plasma nitrided c.p. Ti have been investigated using X-ray diffraction, nuclear reaction analysis, scanning electron microscopy, profilometry, wear tests with stainless steel
Gracey scaler and sonic apparatus, as well as friction coefficient measurements. More than 40 samples have been prepared with different nitriding conditions. Based on the tribooxidative wear process, the whole behavior can be divided in two steps. The first one is the growth of an oxinitride layer $\alpha-\operatorname{Ti}(\mathrm{N}, \mathrm{O})_{\delta}$. During the second step delamination of the oxinitride layer produces debris and increases the friction coefficient.

In conclusion, it is demonstrated that plasma nitriding is useful to improve dental implant tribological behavior.

\section{Acknowledgments}

This work was supported in part by the Brazilian agencies CAPES, CNPq(PRONEX) and FAPERGS.

\section{References}

1. Adell, R.; Eriksson, B.; Lekholh, U.; Brånemark, P.; Jemt, T. Int J Oral \& Maxillofac Implants, v. 5, n. 4, p. 347-359, 1990.

2. Brånemark, P.; Zarb, G.; Albrektsson, T. Prótesis tejidointegradas. La osseointegración en la odontologia clínica. Quintessenz Verlags-GmbH, Berlin, Germany, p. 350, 1987.

3. Jemt, T.; Lekholm, U.; Adell, R. Int J Oral \& Maxillofac Implants, v. 4, n. 3, p. 211-217, 1989.

4. Mezger, P.R.; Creugers, N.H.J. J Dent, v. 20, n. 6, p. 342344, 1992.

5. Rie, K.; Stucky, T.; Silva, R.A.; Leitão, E.; Bordji, K.; Jouzeau, J.Y.; Mainard, D. Surf Coat Technol, v. 74-75, n. 1-3, p. 973-980, 1995.

6. Wang, K. Mat Science \& Eng, A 213, p. 134-137, 1996.

7. Matarasso, S.; Quaremba, G.; Coraggio, F.; Vaia, E.; Cafiero, C.; Lang, N.P. Clin Oral Impl Res, v. 7, n. 1, p. 64-72, 1996.

8. McCollum, J.; O’Neal, R.B.; Brennan, W.A; Van Dyke, T.E.; Horner, J. Periodontol 2000, v. 63, n. 10, p. 802805, 1992.

9. Orton, G.; Steele, D.; Wolinsky, L. Int J Oral Maxillofac Implants, v. 4, p. 305-310, 1989.

10. Rapley, J.W; Swan R.H.; Hallmon W.W.; Mills M.P. Int J Oral Maxillofac Implants, v. 5, n. 1, p. 47-52, 1990.

11. Efeoglu, I.; Arnell, R.D.; Tinston, S.F. Surf Coat Technol, v. 57, n. 1, p. 61-69, 1993.

12. Johansson, C.; Lausmaa, J.; Röstlund, T.; Thomsen, P. J Mater Sc Mater Med, v. 4, n. 2, p. 132-141, 1993.

13. Takadoum, J.; Bennani, H.H. Surf Coat Technol, v. 96, n. 2-3, p. 272-282, 1997.

14. Wilson, S.; Alpas, A.T. Surf Coat Technol, v. 94-95, n. 1-3, p. 53-59, Oct. 1997.

15. Krupa, D.; Basrzkiewicz, J.; Kozubowski, J.A.; Barcz, A.; Sobczak, I.W.; Bilinski, A.; Lewandowska-Szumiel, M.; Rajchel, B. Biomaterials, v. 22, p. 2139-2151, 2001. 
16. Dong, H.; Shi, W.; Bell, T. Wear, v. 225-229, p. 146$153,1999$.

17. Itoh, Y.; Itoh, A.; Azuma, H.; Hioki T. Surf Coat Technol, v. 111, p. 172-176, 1999.

18. Guemmaz, M.; Mosser, A.; Grob, J.J. Appl Phys, A 64, p. 407-415, 1997.

19. Pons, F.; Pivin, J.C.; Farges, G. J Mater Res, v. 2, p. 580-587, 1987.

20. Qiu, X.; Conrad, J.R.; Dodd, R.A.; Worzala, F.J. Metall Trans, v. 21, p. 1663-1667, 1990.

21. Venugopalan, R.; George, M.A.; Weimer, J.J.; Lucas, L.C. Biomaterials, v. 20, p. 1709-1716, 1990.

22. Wierzchon, T.; Fleszar, A. Surf Coat Technol, v. 96, p. 205-209, 1997.

23. Salehi, M.; Bell, T.; Morton, P.H. J Phys D: Appl Phys, v. 25, p. 889-895, 1992.

24. Meletis, E.I.; Surf Coat Technol, v. 149, p. 95-113, 2002.

25. Shima, M.; Okado, J.; McColl, I.R.; Waterhouse, R.B.; Hasegawa, T.; Kasaya, M. Wear, v 225-229, p. 38-45, 1999.

26. Wu, P.Q.; Drees, D.; Stals, L.; Celis, J.P. Surf Coat Technol, v. 113, p. 251-258, 1999.

27. Vitchev, R.G.; Blanpain, B.; Celis, J.P. Wear, v. 231, p. 220-227, 1999.

28. Vancoille, E.; Banpain, B.; Xingpu, Y.; Celis, J.P.; Roos, J.R. J Mater Res, v. 9, p. 992-998, 1994.

29. Shenhar, A.; Gotman, I.; Radin, S.; Ducheyne, P.; Gutmanas, E.Y. Surf Coat Technol, v. 126, p. 210-218, 2000.

30. Yilbas, B.S.; Shuja, S.Z. Surf Eng, v. 16, p. 519-523, 2000.

31. L'Enfant, H.; Laurens, P.; Sainte Catherine, M.C.; Dubois, T.; Amouroux, J. Surf Coat Technol, v. 96, p. 169-175, 1997.

32. Labudovic, M.; Kovacevic, R.; Kmecko, I.; Chan, T.I.;
Blecic, D.; Blecic, Z. Metall Mater Trans, A 30, p. 15971603, 1999.

33. Rodrigo, M.T.; Jiménez, C.; Vázquez, L.; Alonso, F.; Fernández, M.; Martínez-Duart, J.M. J Mater Res, 1998; v. 13, p. 2117-2122, 1998.

34. Santos, C.A. Ion nitriding, Cooperativa Cultural da UFRN, Natal, Brazil, 1989 (in Portuguese).

35. Hudis, M.J. Appl. Phys, v. 44, p. 1489-1492, 1973.

36. Silva, S.L.R.; Kerber, L.O.; Amaral, L.; Santos, C.A. Surf Coat Technol, v. 116-119, p. 342-346, 1999.

37. Rodriguez-Carvajal, J. Physica B, v. 192, p. 55-57, 1993.

38. Kinast, E.J. Structural refinement with the Rietveld method: implementation and essays with the program Fullprof, MSc dissertation (in Portuguese), Instituto de Física - UFRGS, Porto Alegre, Brazil, 2000.

39. Joint Committee on Powder Diffraction Standards. Published by International Centre for Diffraction Data, Swarthmore, Pennsylvania, USA.

40. Feldman, L.C.; Picraux, S.T. Selected low energy nuclear reaction data. In: Mayer, M., Rimini, E., editors. Ion beam handbook for material analysis. London: Academic Press, p. 109-309, 1997.

41. American Society for Testing and Materials, Standard test method for wear testing with a pin-on-disk apparatus, G 99, Philadelphia, USA, 1990.

42. Muraleedharan, T.M.; Meletis, E.I. Thin Solid Films, v. 221, p.104-113, 1992.

43. Hwang, D.H.; Kim, D.E.; Lee, S.J. Wear, v. 225-229, p. 427-439, 1999.

44. Beck, U.; Reiners, G.; Kopacz, U.; Jehn, H.A. Surf Coat Technol, v. 60, p. 389-395, 1993.

45. Badini, C.; Gianoglio, C.; Bacci, T.; Tesi, B. J. LessCommon Metals, v. 143, p.129-141, 1988.

46. Brookshire, F.; Nagy W.W.; Dhuru V.B.; Ziebert G.J.; Chada S. J Prosthet Dent, v. 78, n. 3, p. 286-94, 1997. 